\title{
CHEMICAL CONTROL OF WEEDS IN PASTURES
}

By L. J. MATTHEWS, Weeds Research Officer,

Department of Agriculture, Wellington.

I intend reviewing the progress made to date with chemicals for pasture weed control and to place the use of chemical weedkillers in their right perspective among other farming practices.

Weeds may be classified according to the fertility conditions under which they grow. "Flat" weeds and sorrel are examples of broad-leaved weeds that are most obvious in pastures under low fertility conditions. Docks, buttercups, and various thistles are weeds that thrive best under conditions of high fertility. Al-, though in many cases weeds growing under low fertility conditions are highly susceptible to MCP and may be killed for the cost of a few shillings per acre, it is usually not recommended, that they be treated with weedkillers. Trials have shown that when such weeds are destroyed the total pasture production per acre "may fall, at least for a period, for most of these "low fertility" weeds are palatable and provide feed. Moreover, the destruction of such weeds with a chemical gives but a temporary control; the cause has not been removed and the area is quickly reinfested. Weedkillers, if used at all, should be applied to such areas in conjunction with a definite pasture improvement programme to include oversowing and topdressing and other 'means of increasing fertility. Weedkillers in this instance are only an adjunct to good farming practices and assist in giving a weed-free- area on which to use other pasture improvement' methods.

As opposed to weeds. of low fertility conditions, many of the "high fertility" weeds are upright and bushy and occupy more room per plant than the weeds of low fertility. In spite of good farming practices, with improving fertility these weeds are increasing. This may be attributed to factors that have been introduced to secure high production. Some of these are break grazing, the introduction of upright growing grasses which in some cases are less permanent than 
species such as perennial ryegrass and allow more bare ground in the sward, and also the difficulty in maintaining a proper balance of grasses to clovers. These factors are, accentuated by the introduction -of the electric fence. "The greatest content of "high fertility" weeds today is to be found in areas yielding the greatest butterfat production per acre. Counts of weed seeds content carried out at the Co-operative Dairy Farm at Grasslands, Palmerston North, have shown a very high weed seed content of weeds typical of both high fertility pastures and crops. Both docks and fathen in some paddocks reached or exceeded 2000 seeds per square foot to a 6in. depth.

These weeds are issuing a serious challenge to increased production. Fortunately, most of the "high fertility" weeds are simply controlled by an annual application of either MCP or 24-D. Examples of such weeds are buttercups, thistles, and pennyroyal. On the Hauraki Plains until a few years ago it was usual to see annual buttercups smothering out pasture species in spring and early summer and pennyroyal taking over from the buttercups in early and late summer. Subsequently with an open pasture sward trouble was experienced from a plague of crickets that occupied the cracks that opened up due to the bare ground and also ate out autumn germinating pasture species. This has been rectified by an annual application of MCP or 2,4-D at a cost of a few shillings per acre. The recent marked, increase of giant buttercup (Ranunculus acer) in Taranaki has been effectively controlled by MCP. Californian thistle and other thistles are controlled by MCP or 2,4-D preparations. Docks, however, are more difficult to control with hormone preparations. Seedling docks are quite susceptible, hut established docks are most effectively controlled with PEG 2,4-D at the late flowering stage. The rate of application is high $(2.0 \mathrm{lb}$. acid equivalent per acre) and this -rate causes severe clover damage. In some trials docks have proved highly susceptible to low rates of maleic hydrazide and -have been destroyed without clover damage. Weedkillers for the destruction of high fertility weeds appear to offer the- best means of control and are therefore an essential feature of good farming practice.

A notable example of a high fertility grass weed is barley grass (Hordeum murinum). This weed is increasing in areas such as Hawke's Bay with the building up of fertility. As. the fertility of the hill country 
is increased, so the barley grass is spreading into this country. Like the broad-leaved species mentioned above, this' weed takes advantage of weaknesses in pasture' management. A few years ago the selective control of weed grasses in pasture grasses was an impossibility but today more than six chemicals show promise of being useful in this respect. TCA at $10 \mathrm{lb}$. per acre applied in May has given excellent control of barley grass without damaging clovers or established pasture grasses. At the same time TCA is selective enough to allow the immediate oversowing of clovers after the TCA application. Yet another chemical, Dalapon, when applied to the foliage of grasses, is translocated, as are the hormone preparations, and may eventually prove better than TCA, which is absorbed through the roots of plants.

Critics of chemical weedkillers who consider all weeds can be eliminated by pasture management and/or cultivation commonly point-a finger at clover damage that is sometimes associated with the use of hormone preparations. If the question is asked how much clover a first-class pasture should contain at any given season, no definite answer is supplied. Yet in a pasture that contains a $40: 60$ ratio of clovers to grasses even a temporary check of clovers is severely criticised. Trials have shown that under.both low and high fertility conditions where the clover has been suppressed by weedkillers there has been a marked response of the grasses. In other trials where docks and clovers have dominated the area the docks have been killed, the clover reduced, and a more balanced sward has resulted. In the ryegrass seed production areas of Hawke's Bay clover is not sown because it quickly competes and smothers the ryegrass seed crop. By the third or fourth year there is often sufficient volunteer clover to smother the ryegrass. This clover is then harvested for seed, but up to 50 per cent. of the crop is rejected because of low purity. The fact that no clover is sown allows a more rapid ingress. of barley grass. The problem may be overcome by sowing white clever with the ryegrass but keeping.it in check with weedkillers. The results of the English survey on bloat also indicated that bloat, was more prevalent in areas of high clover content. If we regard a weed as a plant that offers temporary 'or permanent competition to 'more valuable species, then in 'the areas where clovers are' out of balance with 'grass species they must be re- 
garded. as a weed. Now that it is possible to control the content of clover in a pasture, trials have been initiated to determine the amount of clover damage that can be tolerated without affecting pasture production.. In my opinion too much emphasis is placed on clover damage; this damage may in some cases be an advantage where clover dominates the sward.

At some stage in the life of a pasture it-must be broken up and resown. If the weed seed content in the soil is high, sufficient cultivation to reduce this high weed content may be costly both from the operation costs and the loss in production from bare fallowing. Any weed seed brought to the surface has the same chance of striking as the pasture species sown. Thus cultivation, apart from that which is necessary for the preparation of a seed-bed, possibly serves no useful "purpose if another.method of weed control can be employed. In arable areas the introduction of the combine harvester has greatly assisted the spread of weeds. The freedom of choice of implements for cultivation is often restricted by the types of weeds present. For example, areas containing couch must not be rotary hoed or disced if cultivation alone is to be used as the means of weed control. The weed species present-may even affect the species of crops grown.

The weeds that invade a new pasture may be of two types: annual weeds such as fat-hen or perennial weeds such as docks or Californian thistle. Annual weeds are usually eliminated from a, newly sown pasture by grazing, but in many- cases only after much suppression of the pasture species has occurred before the competition of the weeds is removed. Clover, does not establish as quickly as species such as short-rotation ryegrass and the competitive effect of this grass coupled with an early competitive effect of weeds may be sufficient to 'cause a dominance, of short-rotation ryegrass which later declines in production and density because of lack of nitrogen and consequently allows a dominance of clover after the first year. At this stage bloat may be serious. Perennial weeds usually establish quickly and a strike of up to 100 dock seedlings per square foot in high fertility areas is not unusual.

In a detailed trial at the Marton Experimental Area in a spring-sown pasture the amount of white clover was significant\&increased by an application of 
DNBP in the early establishment of the pasture. The effect of this spraying over the untreated control was still apparent two years later. Most of the perennial weeds establishing from seeds are checked sufficiently by DNBP to give a clean pasture. Perennials establishing from suckers or rhizomes usually show too much tolerance to be controlled in a new pasture- with the present available hormone weedkillers. Californian thistle should preferably be sprayed in a resistant crop such as cereals or potatoes or not sprayed with the present hormone preparations until the pasture is six months old. Rhizomatous grasses such as couch (Agropyron repens) should be ploughed, disced, or rotary hoed to break up dormant rhizomes, a resistant crop sudh as brassicas or potatoes sown or planted, and a rate of up to 20 to $301 \mathrm{~b}$. per acre of TCA applied immediately after the crop is sown. The crop may then be followed by an autumn-sown pasture. If this method is employed, relatively weed-free crops are obtained and any couch surviving the crop is usually killed by the cultivation necessary to prepare the autumn seedbed. In this way chemicals may be employed complementary to seed-bed cultivation to give much better weed control than -cultivation alone and to eliminate loss of production by fallowing.

The advantages of weedkillers may be summarised as follows:-

1. Although it is often very easy to kill broadleaved weeds in grasses, weedkillers are often selective enough to eliminate grass weeds in grasses.

2. The control of grass weeds in broad-leaved plants is relatively easy, but it is also possible to kill broad-leaved weeds in broad-leaved species of value.

3. They may be used -hand in hand with cultivation to increase the degree of weed. control and at the same time reduce the number of cultivation operations required and the necessity of fallowing or restriction in the choice of crop sown.

4. They may be used to facilitate harvesting by the combine harvester or potato digger.

5. Their use may'allow the direct heading of small seed crops.

6. Applied in the correct manner they usually give increased production.

Possibly no subject in the whole field of agri197 
cultural technology has advanced as rapidly in \&cent years as the chemical control of weeds.' We are today only on the threshold of 'this- field. What is 'needed is an awakening of public- interest in the seriousness of the weed problem in agriculture and a realisation of the need for adequate staff and facilities for weed control research if full use is to be made of these new developments in the field of weed control.

\section{DISCUSSION}

Q. I used PEG 24D on docks in broad-leaved red clover and killed both.

A. Anybody using PEG 24D on red clover would certainly kill it, at rates high enough to kill docks. Don't use 24D on red clover.

Q. I have barley grass competing with prairie grass, and if I 'spray the barley grass, what effect will it have on the prairie?

A. It would depend on the rate of 'T.C.A. Prairie grass when established will stand un to 10lb. per acre. This rate is sufficient-to kill seeding barley grass. We had a trial at the Marton Experimental Area in which the tolerance of perennial and short rotation ryegrass and timothy was determined, but we do not know the exact tolerance of prairie grass.

Q. Can you kill cutty grass without ploughing up the paddock and without destroying the grass?

A. No; the tolerance of cutty grass is far greater than that of the grasses of value. If. you used T.C.A. after burning it would have to be at very high rates-2001 b. per acre. It should mainly be spot treatment-2oz. per plant.

Q. How can I treat spurrey that is troublesome in the early stages of a chou moellier crop?

A. Use 20lb. per acre of T.C.A. immediately the crop is put in. I.P.C. is far more lethal, but we need to do more work on it, as there may be some reduction in germination under high temperatures.

Q. I have some Algerian oats. I want to oversow with shortrotation ryegrass and white clover. How can I reduce the spurrey and not affect the oversowing?

A. Once clover is at the 2 to 3 true-leaf stage you can use any phenols such as D.N.B.P. You have to get the spurrey young.

Q. What procedure can be recommended for treating docks without doing too much damage to the pasture?

A. PEG 24D will take out docks if applied at the late flowering stage at $21 \mathrm{~b}$. a.e./ac. Applied at this period clover damage is sufficiently severe to check the clover until the following spring. Therefore we have turned to maleic hydrazide, but there have not been enough trials to know whether maleic hydrazide will do the job in all conditions. This chemical should be applied when the docks are still making succulent growth, and is particularly useful for controlling small plants in the rosette stage. Clovers are 
more resistant than grasses to maleic hydrazide; $2 \mathrm{lb}$ of maleic hydrazide will put grasses to sleep for 3 to 4 weeks.

Q. How would you clear out spurrey and grasses in established stands of lucerne?

A. "Chemicals ale 'available' that' will clear: up 'a lucerne crop until it can 'be treated with a more drastic chemical. If you have a lot of weedy lucerne then you cannot get rid of the weeds without some'reduction in the luderne. Spurrey and grasses can be taken care of as soon as the onset of dormancy in the lucerne with T.C.A. at 20 to $30 \mathrm{lb}$. You will never kill out all the grasses, with'one application and a second application should be made a month or so before the lucerne resumes growth. Such treatment will depress the lucerne growth up to the first cut. If you can bring up the lucerne to two years old you can use substituted ureas, which just sit in the top half-inch or so of soil and kill all seedlings. Trials in New Zealand have been down for only 18 months, which, is not long enough to determine the period of weed control. A few pounds of C.M.U. will keep out seedling weeds from one dormant season to the next.

Q. What can be recommended for permanent control of buttercup and what effect will, it have on other species in the pasture?

A. Buttercups are so susceptible that you can use the most selective weed-killers such as water-based M.C.P. Their effect on clover is only very slight. The follow-up depends on the farmer. Unfortunately weedkillers have no fertilising properties, so it depends on the farmer's pasture management whether he keeps the buttercup out. Buttercup can be knocked each year as it appears, but I would rather see pasture improvement after the first treatment than application of weedkillers year after year. Q. How can you prevent infestation of Jucerne-cocksfoot pas-

A. There is an array of chemicals available; $3,4-\mathrm{D}$ and 4-C will do the job.

Q. Are there any set requirements in regard to rate of dilution of weedkillers with water?

A. Water has no weedkilling properties; the essentials are: 1 . See that YOU apply the required amount of acid equivalent on the area. 2. -Ensure a thorough cover. 3. Avoid, excessive run-off. You can put in one gallon of water or 1000 . Weedkillers act through the rooting or leaf systems of plants. If hormones are -sprayed on in light applications (100 gals. to the acre) all the intake is through the leaf surface. If the application is to bare ground, uptake is through the roots. If you are spraying weeds in pastures and the weedkiller is diluted to a few thousand gallons and it gets into the soil, then the weedkiller will be non-selective and will attack grasses.

Q. If enough. spray has to be used to cover the plant foliage, can it be taken that 'the finer the spray is the less water will have to be used, and the coarser the spray used the more water will be necessary?

A. You have to take the equipment into account and he amount of water needed is tied up with the size of nozzle and the pressure used. 